\title{
Advances in Studies on Nitrogen and Phosphorus Removal by Microalgal-Bacterial Consortia
}

\author{
Ruimin $\mathrm{Mu}^{1}$, Qingyang Guo ${ }^{1}$, Feng $\mathrm{Qi}^{1}{ }^{1,}$, Yantian $\mathrm{Jia}^{1}$, Qianya Meng ${ }^{1}$, and Gejiang $\mathrm{Yu}^{1}$ \\ ${ }^{1}$ School of Municipal and Environmental Engineering, Shandong Jianzhu University, Jinan 250101, China
}

\begin{abstract}
With the development of life and industry, the nutrients in sewage increased gradually. The emerging symbiotic system of algal and bacteria has remarkable effect in removing nutrients such as nitrogen and phosphorus. In this paper, the influence of nitrogen and phosphorus on bacteria-algal consortia and the absorption mechanism of nitrogen and phosphorus by the interaction of bacteria-algal consortia were analyzed, and a variety of methods for studying bacteria-algal consortia were summarized, mainly using isotope tracer technology to study the research results of bacteria and algae absorbing nitrogen and phosphorus in water. This method is of great significance for analyzing the mechanism of the treatment of nitrogen and phosphorus by the bacterial-algal symbiosis system from the microscopic point of view.
\end{abstract}

\section{Introduction}

With the development of industrial level and the improvement of people's living quality, water pollution is becoming increasingly serious. The excess nutrients in water, such as nitrogen and phosphorus, can lead to eutrophication of water, affecting aquatic ecological balance and human health[1]. Therefore, it is of great significance to improve water quality and reduce treatment costs. At present, the commonly used denitrification process is activated sludge process, which uses nitrification and denitrification in activated sludge bacteria to remove nitrogen under aerobic and anoxic reaction conditions respectively. The phosphorus removal process relies on the release and absorption of phosphorus by phosphorous accumulating microorganisms under anaerobic and aerobic conditions respectively[2]. The conventional treatment techniques above can remove most suspended solids and organic pollutants, but the removal effect of nitrogen and phosphorus is not very ideal[3].

Studies have shown that the microalgal-bacterial consortia is an emerging wastewater treatment technology with lower cost and better treatment effect[4], because the interaction between bacteria and algae can improve the removal rate of nitrogen and phosphorus by the symbiosis. The growth of bacteria and algae depends on nutrients such as nitrogen and phosphorus, and their combination can produce synergistic effects, improving the nitrogen fixation potential and the ability to assimilate phosphorus[5,6]. The interaction between bacteria and algae is very complex, including nutrient exchange, signal transduction and so on[7]. For example, the signal molecule AHL mediated quorum sensing can change the related performance of microorganisms and regulate the community structure[8], and the signal molecule indole acetic acid (IAA) is also positively correlated with the removal rate of ammonia nitrogen in wastewater[9].

At present, microalgal-bacterial consortia have been used in a wide range of fields, including livestock and poultry sewage, saline marine sewage and domestic sewage, which can serve for the removal of nutrients and the commercial production of microbial metabolites. The study on the absorption of nitrogen and phosphorus by microalgal-bacterial consortia is of great significance for guiding the degradation of nutrients and the purification of wastewater[10]. There are many techniques for studying microalgal-bacterial consortia. Among them, stable isotope analysis of $15 \mathrm{~N}$ is an established technology to determine the source of nitrogen and the contribution of different sources to microorganisms, as well as to track the whereabouts of nitrogen in microorganisms[11]. More and more scholars are interested in using this technology to study the dynamic behavior of nutrients in organisms and water[12]. However, few reviews have focused on the use of isotope tracer techniques to study the removal of nitrogen and phosphorus by microalgal-bacterial consortia. In this paper, the absorption of nitrogen and phosphorus by the interaction of microalgal-bacterial consortia and the application prospect of isotope tracer technique in consortia are introduced.

\section{Removal effects of nitrogen and phosphorus on microalgal-bacterial consortia}

Nitrogen $(\mathrm{N})$ and phosphorus $(\mathrm{P})$ are converted by various valence states and combined states under biological action in nature. Bacteria and algae are two types of organisms closely related to each other in the water ecosystem. Microalgae are photosynthetic autotrophic

\footnotetext{
* Corresponding author: qifeng@sdjzu.edu.cn
} 
microorganisms, which can convert nitrogen, phosphorus and other inorganic substances in sewage into organic matter through photosynthesis, and at the same time release $\mathrm{O}_{2}$ for the growth of bacteria, Figure 1. Under the action of microorganisms, nitrogen in the water is converted to ammonia, and in the presence of oxygen, ammonia nitrogen in the water is converted to nitrate nitrogen by nitrifying bacteria[13]. Aerobic bacteria in activated sludge oxidize and decompose organic matter and produce nitrate which can be used by microalgae to promote their photosynthesis and growth and reproduction[14].

Activated sludge can remove phosphorus by releasing phosphorus under anaerobic conditions and absorbing phosphorus under oxygen conditions respectively. However, phosphorus can be used to synthesize ATP by absorption and assimilation of microalgae[15], and phosphate can promote the growth of the community structure of microalgae and phosphorus accumulating bacteria[16].
The concentration of nitrogen and phosphorus had significant effects on the growth and community structure of the microalgal-bacterial consortia. Different combinations of algae species and strains have different nutrient removal efficiency in wastewater. For different sewage, the dominant communities of microorganisms change, and the communities interact with each other to form the appropriate microalgal-bacterial consortia[17]. Due to the "luxury uptake" of nutrients by microalgae and bacteria, the uptake of $\mathrm{N}$ and $\mathrm{P}$ by microalgal-bacterial consortia increased as the initial $\mathrm{N}$ and $\mathrm{P}$ concentration increased, far exceeding the stoichiometric $\mathrm{N}$ and $\mathrm{P}$ required for the corresponding increase in biomass[18]. However, the experiment proved that too high N/P ratio would slow down the growth rate of algal cell biomass and decrease the bacterial density in different degrees in the later period of the experiment[19].

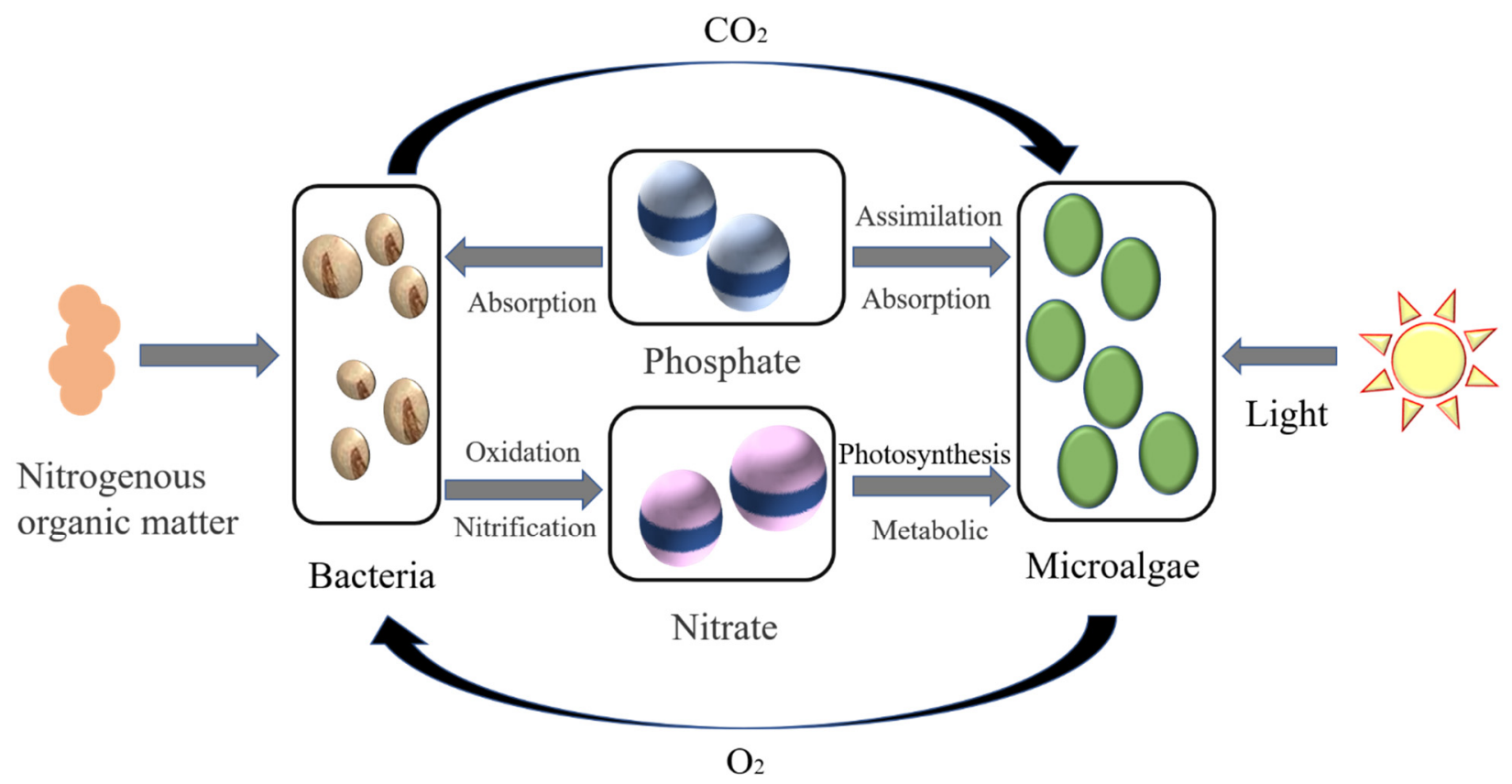

Figure 1. Nitrogen and phosphorus in wastewater are removed by microalgal-bacterial consortia.

\section{$3 \mathrm{~N}$ and $\mathrm{P}$ absorption by interaction of microalgal-bacterial consortia}

Some scholars believe that there are a lot of interactions between microalgae and heterotrophic bacteria mediated by nitrogen and phosphorus in the state of poor nutrition[20]. For example, nitrogen-fixers provide inorganic nitrogen to scenedesmus, Escherichia coli provides inorganic phosphate to host microalgae, and Pseudomonas maintains phosphorus concentrations suitable for Microcystis aeruginosa through phosphorus transfer[21]. The treatment effect of algae or activated sludge on nutrients and COD in wastewater is far less than that of microalgal-bacterial consortia. Choi found that the removal efficiency of total $\mathrm{N}$ and total $\mathrm{P}$ in the bacterial-algal co-culture reactor was 3.4 and 6.5 times higher than that in the pure nitrification reactor[22]. In the treatment of nutrients in sewage by algae alone, due to the photoinhibition, algae autotrophic growth is slow, and the loss of activated sludge that provides carbon source, $\mathrm{CO} 2$ only comes from the air, photosynthesis of algae is restricted, resulting in low efficiency of algae removal of nutrients. Both algae and nitrifying bacteria in activated sludge can use ammonia and phosphate in sewage as common substrates[22]. In addition, when the ratio of microalgae and activated sludge was 5:1, the removal efficiency of total $\mathrm{N}$ and total $\mathrm{P}$ was the highest, which were $95.8 \%$ and $93.5 \%[23]$. The $\mathrm{N}$ and $\mathrm{P}$ removal rates of the bacterial-algal symbiosis system are summarized in Table 1.

Algae and bacteria not only exist symbiosis, but also inhibit and compete. Bacteria can inhibit the growth of algae by competing with nitrogen and phosphorus nutrient elements, which is one of the effective ways to control 
fresh water blooms and maintain aquatic ecological balance.

Table1. Summarization of $\mathrm{N}$ and $\mathrm{P}$ removal rates in wastewater by microalgal-bacterial consortia.

\begin{tabular}{|c|c|c|c|c|c|c|}
\hline Bacteria & Microalgae & Type of wastewater & $\mathrm{TN}$ & TP & $\mathrm{NH}_{4}{ }^{+}-\mathrm{N}$ & Reference \\
\hline $\begin{array}{l}\text { Brevundimona } \\
\text { bullata }\end{array}$ & \multirow[t]{2}{*}{ Chlorella } & \multirow{2}{*}{$\begin{array}{l}\text { Light polluted } \\
\text { water }\end{array}$} & $64 \%$ & $95.4 \%$ & & \multirow[t]{2}{*}{ [9] } \\
\hline $\begin{array}{c}\text { Pseudomonas } \\
\text { panipatensis }\end{array}$ & & & $68 \%$ & $65.7 \%$ & & \\
\hline $\begin{array}{c}\text { Photosynthetic } \\
\text { bacteria }\end{array}$ & $\begin{array}{l}\text { Chlorella } \\
\text { albumen }\end{array}$ & Artificial sewage & $95 \%$ & & & [31] \\
\hline $\begin{array}{l}\text { Activated } \\
\text { sludge }\end{array}$ & Chlorella & $\begin{array}{l}\text { Wastewater from } \\
\text { livestock and } \\
\text { poultry breeding }\end{array}$ & & $95.1 \%$ & $83.2 \%$ & [2] \\
\hline $\begin{array}{c}\text { Associated } \\
\text { bacteria }\end{array}$ & $\begin{array}{l}\text { Freshwater } \\
\text { algae }\end{array}$ & Sanitary sewage & & $92.3 \%$ & $95.6 \%$ & [4] \\
\hline $\begin{array}{l}\text { Activated } \\
\text { sludge }\end{array}$ & Hybrid algae & Artificial sewage & & $83.3 \%$ & $94.2 \%$ & [24] \\
\hline
\end{tabular}

\section{Advances in techniques for the study of microalgal-bacterial consortia}

With the increasing research on microalgal-bacterial consortia, the selection of appropriate techniques and specific tools plays an important role in the research. The selection of different research methods is helpful to the stable establishment of the bacteria-algal co-culture system, so that it can better serve the sewage treatment and the protection of aquatic ecological balance. In the macroscopic analysis, the research is mostly through physical and chemical detection methods. By measuring the contents of nitrogen and phosphorus before and after treatment, the removal efficiency of microalgal-bacterial consortia on nitrogen and phosphorus in wastewater was analyzed.

In the microscopic aspect, the research methods include microscopy, flow cytometry, cell sorting, omics and secondary ion mass spectrometry.

\subsection{Microscopy}

Microscopic observation of consortia can be used to obtain details of their cell morphology and composition. Microbial composition of mixed samples of bacterialalgal systems and water samples can be observed by microscope, and the increase of the number of dominant algae species and bacteria can be observed, and it can also be proved that nitrogen and phosphorus in sewage have been removed[24].

\subsection{Flow cytometry and cell sorting}

Flow cytometry and cell sorting are also microscopic techniques that have been used to measure specific cellular components of microalgae and bacteria in bacterial-algal systems. For example, analysis of polyphosphate-accumulating bacteria can be done by staining polyphosphate particles with fluorescent dyes DAPI and tetracycline hydrochloride by flow cytometry[5].

\subsection{Omics}

Metagenomics methods have also been applied to study the community structure of bacteria and algae, and to study the changes of dominant communities by sequencing genes, so as to improve the efficiency of consortia in wastewater treatment. A series of methods including genomics, transcriptomics, proteomics and metabolomics have been applied to the study of bacteriaalgal symbiosis[5].

\subsection{Secondary ion mass spectrometry}

Secondary ion mass spectrometry (SIMS), such as isotope ratio mass spectrometry (IRMS), can be used to study the function and metabolism of individual microorganisms in a microbial community at the cellular level. Nanomaterials combined with fluorescence in situ hybridization were used to study and image the metabolic activity and absorption rate of microbial cells in a complex microbial population[25]. The multi-isotope imaging mass spectrometry (MIMS) showed the binding level of $15 \mathrm{~N}$ in bacteria. This method can be used to study bacteria in the natural environment and explore the activity of nitrogen nutrient symbionts in algae and bacterial cell tissue. It will be a powerful tool for studying the effect of nitrogen fixation in the future[26].

Isotope tracer technology is to use the mass spectrometer or element analyzer, radioactive isotope as a tracer, used to study the distribution, migration, enrichment rules of a substance[25]. The combination of isotope labelling experiments with other methods such as nanotechnology will open up new directions for the analysis of microbial communities and their metabolic functions[27]. 
DE - Bashan to the isotope labeling algal-bacterial system experiment, will mark the party and on the other side of the untagged culture together, and then use the secondary ion mass spectrometry analysis of each element transfer between microbial cells and bacterial cell adhesion over the surface of the algal cells and release metabolite, proved that the nitrogen molecules by switching between two kinds of microbes, and a symbiotic interaction that promotes the growth of the microalgalbacterial consortia[28]. Stable isotope analysis of nitrogen $(14 \mathrm{~N} 15 \mathrm{~N})$ can determine the source of nitrogen in complex environments and analyze the contribution ratio of different sources[11]. For example, Cao used stable isotopes to track the source and contribution ratio of organic matter in sediments and analyze the causes of eutrophication of water bodies, which has indicative significance for the protection of ecological environment[29]. Han et al. added stable ${ }^{15} \mathrm{~N}$ isotopes to the experiment, which showed that microalgae would preferently absorb and assimilate reduced ammonia nitrogen in water, followed by oxidized nitrate nitrogen, and different algae species had different rates of nitrogen absorption[30]. Wang et al. used stable isotopes to investigate the absorption rates of ammonia nitrogen, nitrate nitrogen and urea nitrogen by bacteria-algal combination under different temperature, light and salinity conditions[31]. Based on the stable isotope fractionation effect, Meng et al. established a model for the value of $\delta 15 \mathrm{~N}$ in activated sludge and the denitrification efficiency of the whole system, which improved the efficiency of sewage treatment and was of great significance for the denitrification process of water plants[32].

Different forms of phosphorus can be tracked by isotope labeling, but only $31 \mathrm{P}$ is stable isotope, and the $\mathrm{P}$ $\mathrm{O}$ bond is relatively stable chemical bond[33], so the use of phosphate oxygen isotope can be used to study the direction of phosphorus in aquatic ecosystems[12]. Elsbury et al. used phosphate oxygen isotope tracer techniques to distinguish between different sources of phosphate and their relative contributions[34]. Based on the phosphate oxygen isotope tracer technique, McLaughlin et al. used $\delta^{18} \mathrm{O}_{\mathrm{p}}$ as a tracer to study the phosphorus cycling in the water body of San Francisco Bay[35].

\section{Conclusion}

The ability of microalgae to remove nutrients such as nitrogen and phosphorus in wastewater was combined with the ability of bacteria to degrade pollutants, and construct microalgal-bacterial consortia to achieve water purification and aquatic ecosystem balance is considered to be a very promising treatment technology, which is cheaper than traditional wastewater treatment technology, and has been widely studied. The interaction between algae and bacteria and their metabolic functions can be further studied by means of microscopy and omics. The use of advanced analytical tools also provides more comprehensive and detailed information for the construction of microalgal-bacterial consortia that can efficiently remove nitrogen and phosphorus. The application of isotope tracer technique to study the specific trends of nitrogen and phosphorus in microalgalbacterial consortia can further explore the interaction and removal mechanism between the two elements from the microscopic molecular dimension, which is more meaningful than the study of removal rate alone. This method is helpful to improve the efficiency of wastewater treatment and to construct suitable microalgal-bacterial consortia for wastewater with different $\mathrm{N}$ and $\mathrm{P}$ concentrations. However, more research is needed.

\section{Acknowledgement}

This review was funded by "Youth Innovation Technology Project of Higher School in Shandong Province, grant number 2019KJD003; Shandong Province Natural Science Foundation, grant number ZR2019MEE104; Shandong Province Water Conservancy Research and Technology Extension Project, grant number SDSLKY201812.

\section{References}

1. H.ZENG, Q.LIU, C.XIAO, Optimization of microalgae-bacteria symbiosis system for the advanced treatment of livestock wastewater using response surface methodology,Journal of AgroEnvironment Science,39(6),1368-1379 (2020)

2. H.LIANG,Y.ZHANG,Study on the removal of nitrogen and phosphorus from sewage by Co-culture of immobilized sludge and immobilized Chlorella, Guangxi Sciences, 26(2),215-221 (2019)

3. B.GAO,J.CHENG,Y.CUI, Study on the purification of domestic sewage by immobilized alga with fibrous materials and its influencing factors, Jiangsu Agricultural Sciences, 46 (11) ,276-279(2018)

4. M.GAO,Study on Removal of Nitrogen and Phosphorus and Heavy Metals from Wastewater by Alga-bacteria System.(2016)

5. I.A.Perera,S.Abinandan,S.R.Subashchandrabose,K. Venkateswarlu,R.Naidu,M.Megharaj,Advances in the technologies for studying consortia of bacteria and cyanobacteria/microalgae in wastewaters, Crit Rev Biotechnol,39 (5), 709-731 (2019)

6. N.Renuka,A.Guldhe,R.Prasanna,P.Singh,F.Bux,Micr oalgae as multi-functional options in modern agriculture: current trends, prospects and challenges, Biotechnol Adv,36 (4), 1255-1273(2018)

7. A.Kouzuma, K.Watanabe, COB, Exploring the potential of algae/bacteria interactions, Curr Opin Biotechnol,33, 125-9(2015)

8. Y.PANG, Z.WU, T.AN, Z.SUN, M.GOU, Quorum Sensing Mediated by Signal Molecule AHL in Wastewater Biological Treatment, Technology of Water Treatment, $\mathbf{4 6}$ (11)(2020)

9. T.CHEN,The Study on Application and Mechanism of Bacteria-Algae Symbiosis and Bioaugmentation Technology in Wastewater Treatment .(2017) 
10. S.R.Subashchandrabose,B.Ramakrishnan,M.Meghar aj, K.Venkateswarlu, R.Naidu, Consortia of cyanobacteria / microalgae and bacteria: biotechnological potential, Biotechnol Adv,29(6), 896-907(2011)

11. M.J.Ochoa-Izaguirre,M.F.Soto-Jimenez, Variability in nitrogen stable isotope ratios of macroalgae: consequences for the identification of nitrogen sources, J Phycol,51 (1), 46-65(2015)

12. Q.CHU,J.FAN,G.FENG, New Advance of The P Isotopic Tracing In The Ecology And ResourceEnvironmental Sciences: A Review,26 (05), 828837(2012)

13. P.ZHAO, The ecological respond of microorganisms to environment in different nitrogen polluted water, (2016)

14. M.DIAO,J.LIU,W.WANG,W.HUA,S.WU,S.SUN , Y.CHENG, Impact of algae-bacteria symbiotic system on wastewater treatment and biomass accumulation of microalgae, Environmental Engineering, 36 (03) , 8-12(2018)

15. Y.Collos,A.Vaquer,P.Souchu, Acclimation of Nitrate Uptake by Phytoplankton To High Substrate Levels, Journal of Phycology, 41 (3), 466-478(2005)

16. R.Mu,Y.Jia,G.Ma,L.Liu,K.Hao,F.Qi,Y.Shao,Advanc es in the use of microalgal-bacterial consortia for wastewater treatment: Community structures, interactions, economic resource reclamation, and study techniques, Water Environ Res ,(2020)

17.H.WANG , W. WANG , Y. SHENG,Influences of sewage treatments technologies on microalgae and bacteria community structures, China Environmental Science, 38(10), 3761-3766(2018)

18. V.Ashok,A.Shriwastav,P.Bose, Nutrient removal using algal-bacterial mixed culture, Appl Biochem Biotechnol ,174 (8), 2827-38(2014)

19. Q.LIU,Establishment of stable culture and optimization of symbiltic system of bacteria and algae,(2018)

20. B.Zhang,W.Li,Y.Guo,Z.Zhang,W.Shi,F.Cui,P.N.L.Le ns,J.H.Tay, Microalgal-bacterial consortia: From interspecies interactions to biotechnological applications, Renewable and Sustainable Energy Reviews ,118(2020)

21. L.Jiang, L.Yang, L.Xiao, X.Shi, G.Gao, B.Qin, Hydrobiologia, Quantitative studies on phosphorus transference occuring between Microcystis aeruginosa and its attached bacterium (Pseudomonas sp.),581(1),161-165 (2007)

22. K.J.Choi, T.H.Han, G.Yoo, M.H.Cho, S.J.Hwang, Co-culture Consortium of Scenedesmus dimorphus and Nitrifiers Enhances the Removal of Nitrogen and Phosphorus from Artificial Wastewater, KSCE Journal of Civil Engineering, 22 (9),3215-3221(2017)

23. Y.Su, A.Mennerich, B.Urban, Synergistic cooperation between wastewater-born algae and activated sludge for wastewater treatment: influence of algae and sludge inoculation ratios, Bioresour Technol,105, 6773(2012)

24. K.HAO,W.CHEN,R.MU,F.QI,H.WANG,Study on the removal of nitrogen and phosphorus by bacteria and algae system,Journal of Shandong Jianzhu University, 34 (05), 50-54(2019)

25. D.Gao,X.Huang,Y.Tao, A critical review of NanoSIMS in analysis of microbial metabolic activities at single-cell level, Crit Rev Biotechnol,36(5), 884-90(2016)

26. C.Lechene,F.Hillion,G.M.Mahon,D.Benson,A.M.K1 einfeld,J.P.Kampf,D.Distel,Y.Luyten,J.Bonventre,D. Hentschel,K.M.Park,S.Ito,M.Schwartz,G.Benichou, G.Slodzian, High-resolution quantitative imaging of mammalian and bacterial cells using stable isotope mass spectrometry, Journal of Biology,5(2006)

27. N.Musat,B.Adam,M.M.M.Kuypers,Nano-Secondary Ions Mass Spectrometry (nanoSIMS) coupled with in situ hybridization for ecological research.(2017)

28. L.E.de-

Bashan,X.Mayali,B.M.Bebout,P.K.Weber,A.M.Detw eiler,J.P.Hernandez,L.Prufert-Bebout,Y.Bashan,

Establishment of stable synthetic mutualism without co-evolution between microalgae and bacteria demonstrated by mutual transfer of metabolites (NanoSIMS isotopic imaging) and persistent physical association (Fluorescent in situ hybridization), Algal Research,15,179-186(2016)

29. H.CAO , Z.ZHANG, W. HE, X.HUANG, X.PU,Study on the Change process of the ecological environment in the Zhanjiang Bay through the organic carbon isotope technique,Journal of Ocean Technology, 39 (01) 57-63(2020)

30. F.HAN,Z.ZHAO,D.LI,L.ZHANG, The use of ${ }^{15} \mathrm{~N}$ to measure nitrogen uptake of phytoplankton, Oceanologia ET Limnologia Sinica, 50 (04),811821(2019)

31. P.WANG, Effects of temperature, salinity and light intensity on nitrogen absorption of bacteria-algae system, (2020)

32. N.MENG, P.JIN, H.JIN, X.LI, Evaluation of the nitrogen removal performanceinactivated sludgeprocess based on nitrogen stable isotope fractionation principle, Acta Scientiae Ccircumstantiae,38(5),1828-1834 (2018)

33. C.ZHANG, H. JI, Z.CHE,The application of phosphate oxygen isotope in organophosphorus degradation, Journal of Shandong Agricultural University,49 (06) ,1008-1014(2018)

34. K.E.Elsbury,A.Paytan,N.E.Ostrom,C.Kendall,M.B.You ng,K.Mclaughlin,M.E.Rollog,S.Watson, Using Oxygen Isotopes of Phosphate to trace phosphorus sources and cycling in lake Erie,Environmental Science\&Technology, 43(9),3108-3114(2009)

35. K.McLaughlin,C.Kendall,S.R.Silva,M.Young,A.Paytan, Phosphate oxygen isotope ratios as a tracer for sources and cycling of phosphate in North San Francisco Bay, California, Journal of Geophysical Research,111(2006) 